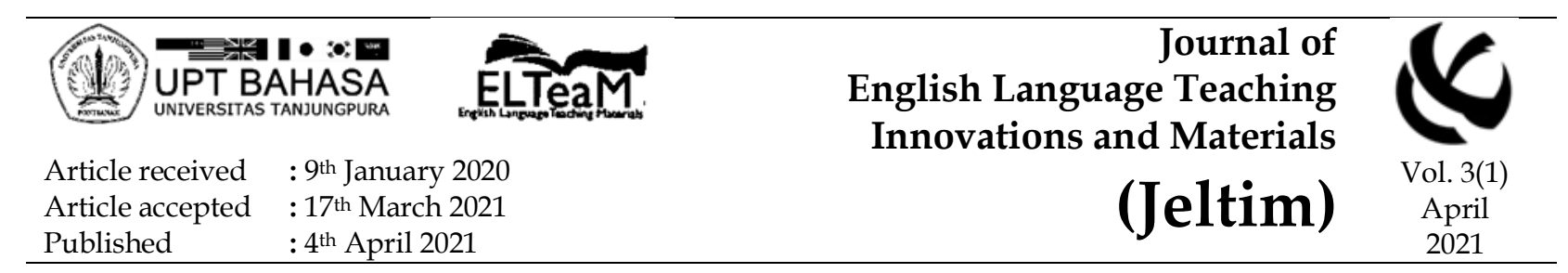

\title{
Clustering technique to improve ability of generating ideas in recount text writing
}

\author{
Hilda Mutia Sari ${ }^{1}$, Y. Gatot Sutapa ${ }^{2}$, Clarry Sada ${ }^{3}$ \\ ${ }^{1}$ Independent educator in Kuching, Sarawak, Malaysia \\ mutiasarihilda@gmail.com \\ ${ }^{2}$ Master Study Program of English Language Education, Teacher Training and \\ Education Faculty, Universitas Tanjungpura, Pontianak, Indonesia \\ yohanes.gatot.sutapa.y@fkip.untan.ac.id \\ ${ }^{3}$ Master Study Program of English Language Education, Teacher Training and \\ Education Faculty, Universitas Tanjungpura, Pontianak, Indonesia \\ clarry.sada@fkip.untan.ac.id
}

\section{DOI: $\underline{\text { http://dx.doi.org/10.26418/jeltim.v3i1.38880 }}$}

\begin{abstract}
One of learners' difficulties in the English language subject is writing. It also happened at MTs Darussalam Sengkubang, Kalimantan Barat. This classroom action research was conducted in the MTs to solve the learners' difficulty in writing recount texts. The classroom action research that was used in this study consisted of planning, acting, observing, and reflecting in cyclical process. In this research, the data were collected using field note, observation checklist, interview guideline, documentation, and individual test. The finding was that there was improvement on learners' behavior in the process of teaching and learning through the implementation of clustering technique. The researcher concluded that clustering technique was improving the learners' ability in generating ideas in recount text writing. Therefore,clustering technique could help the learners in learning process because this technique encouraged learners to learn actively.
\end{abstract}

Keywords: Clustering Technique; Recount Text; Writing;

How to cite this paper: Sari, H.M., Sutapa, G.S., \& Sada, C. (2021). Clustering Technique to Improve Learners' Ability in Generating Ideas in Recount Text Writing. Journal of English Language Teaching Innovations and Materials (Jeltim), 3(1), 27-40. DOI: http://dx.doi.org/10.26418/jeltim.v3i1.38880

Writing is one of skills in English that is accounted as a difficult skill among other skills. Moreover, teaching writing is taught since junior high

Journal of English Language Teaching Innovations and Materials (Jeltim), 3(1), 25-38

Copyright ( 2021 by Jeltim, e-ISSN 2657-1617 
school which is concern to develop learners' ability in writing. There are some genres of texts taught in Year-8 such as descriptive text, procedure text, narrative text, and recount text. It was aimed to develop language skills like writing. Vocabulary is required by learners to write a text.

As indicated in the classroom observation, many learners encountered problem in their writing activity especially in finding words to explore their ideas. Learners faced difficulties in choosing the appropriate words to use. In writing, the learners need to generate their ideas into the series of paragraph. The well structured ideas will form the writing coherently.

Many learners still had difficulties to generate their ideas based on the recount text writing structures. The learners did not know what to write and how to write it properly. Some learners faced difficulties dealing with organization of recount text including how to start to generate ideas in the orientation part and the other part of recount text. They found it difficult to deal with developing ideas and selecting words that met the contexts when they generated the ideas. The problems encountered due to the difference of English with the first language so it is difficult for them. The learners also face difficulties to develop ideas in writing. In addition, they also have the bad attitude toward the learning of writing itself.

As an attempt of solving the aforementioned problems, in this study the researcher facilitated the learners reduce their difficulties in writing a recount text. To help the learners dealing with this problem, teachers used various technique in teaching and learning process to make the learners interested and enthusiastic during the learning process. There are several methods or techniques that teachers can use to teach writing and clustering technique is included. The researcher tried to use the technique to help learners improve their recount text writing. Clustering technique can be used effectively in prewriting activities. It is useful to help learners generate ideas in writing, especially writing a recount text writing. So, they will be able to organize their ideas by clustering those ideas to form into the whole idea. Clustering can be useful in a brainstorming activity for producing the piece of writing (Adriati. 2013, p. 40). This Technique can help the learners with associative thinking (Kellog. 1994, p. 134) because it can help learners work with the concepts and ideas, associated.

Clustering technique was chosen in this research to help learners generate their ideas to write a text, especially recount text. By using clustering technique it is expected that we will be able to help learners develop ideas easily in writing recount text. The writer chose the clustering technique because there were several purposes such as learners can enhance their writing skill and

Journal of English Language Teaching Innovations and Materials (Jeltim), 3(1), 25-38 Copyright ( 2021 by Jeltim, e-ISSN 2657-1617 
tried new solution to create an effective note to produce simple recount text. The Clustering technique helps the learners write easier and interested in writing activity so learner can increase their motivation to write. Furthermore, by using clustering technique the researcher hoped that learners could develop ideas in the beginning step of their writing activities.

A previous research that was conducted by Adriati (2013) investigated the effects of the implementation clustering activities in the teaching of narrative text writing. One of the findings of the study was that clustering activities tended to be effective to organize learners' ideas and it was very potential technique in writing. Meanwhile, this research focused on implementing clustering technique to improve learners' recount text writing. Because it has been proven that clustering technique could be used to help learners in generating ideas in writing, we came to an idea that this technique would be effective to be implemented in teaching recount texts.

\section{METHOD}

In this study, the researcher used classroom action research (CAR) method. The purpose of using the method was using clustering technique to improve learners' ability to write a recount text. Mills, as re-explained in Creswell (2012), described action research as systematic sets of steps or procedures used by teacher researchers to collect data about and to improve their ways of teaching in a particular educational setting and to improve their learner process of learning. As cited in Koshi (2005), Kemmis and McTaggart explained that action research basically contains four main steps: planning, acting, observing and reflecting. The four steps are done integratedly in a cyclical process.

The research subject was Class - A learners of Year - 8 in MTs Darussalam Sengkubang Academic Year 2017 / 2018. There were 22 female learners in the class (learning group). Not much different from the learners of other classes, the learners in this class had difficulties in writing in English. The topic of teaching when this research was conducted was recount text writing. However, in their daily school activities, the learners were enthusiastic in learning English. Most of them had good interest in English subject.

The data in this research were collected through two ways, namely observation and measurement. In the observation process, the data that were collected were those that were relates to the focus of this research. The information was documented using recording, observation checklists, field notes, and interview note. To complete the data, a written test was given to the learners; that is recount text writing test. To get the data of the learners'

Journal of English Language Teaching Innovations and Materials (Jeltim), 3(1), 25-38

Copyright ( 2021 by Jeltim, e-ISSN 2657-1617 
achievement in the sub skill of recount text writing, every individual answers sheet of learners' work were collected and checked carefully by the researcher. In this research, the researcher was the teacher researcher and was assisted by a collaborator (also an English teacher). The collaborator helped the researcher mainly in collecting the data. She observed the learners' activities when the teacher researcher conducted the teaching and learning process as the acting step of the action research.

The data were analyzed using quantitative and qualitative ways. The qualitative way was used to know the improvement of learners' classroom activities. Meanwhile, the quantitative ways were conducted to support the result of the data analysis of the learners' improvement in the teaching and learning process.

\section{FINDINGS}

This classroom action research was conducted in 3 cycles to the Year - 8 learners of MTs Darussalam Sengkubang. In this research, the researcher acted as the teacher, while another English teacher acted as the collaborator. The researcher and her collaborator observed learners' behavior during the teaching and learning by using clustering technique in generating ideas of recount text writing.

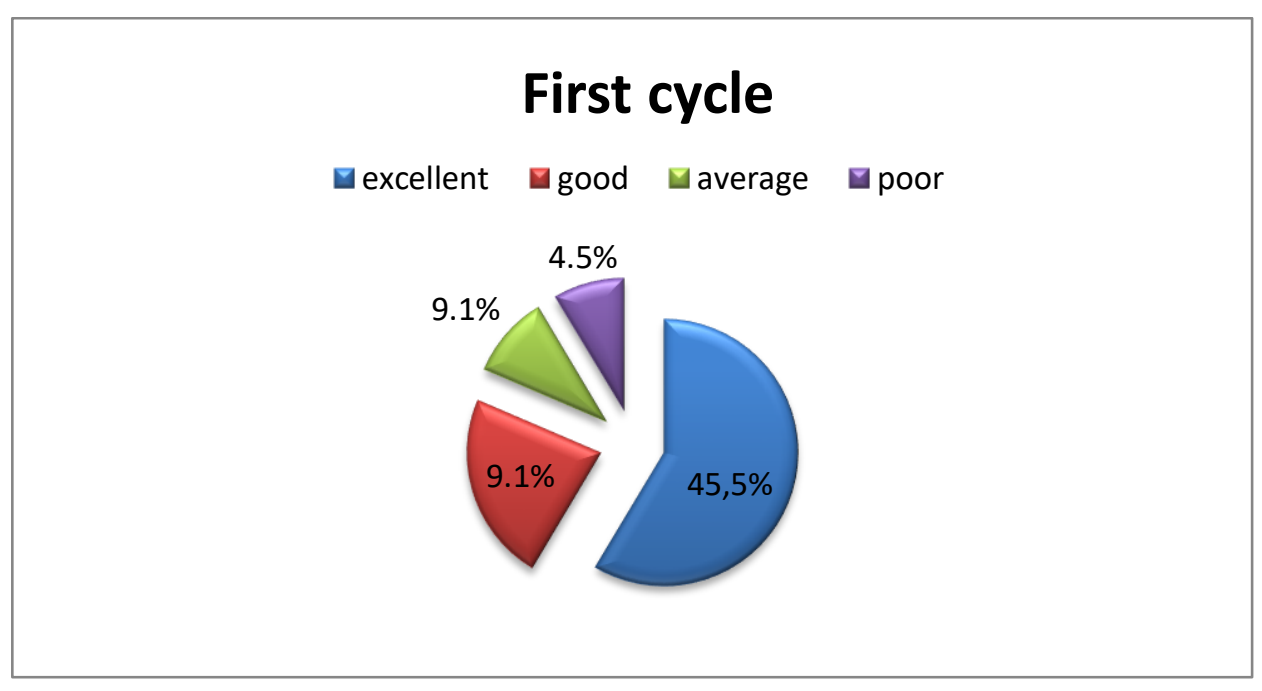

Chart 1. Learners' Firs Cycle Writing Test Result

This research article of the implementation of clustering technique to improve learners' recount text writing is written by following classroom action research procedure. The data of this research were collected from the teaching and learning process that were conducted in three cycles. The collected data

Journal of English Language Teaching Innovations and Materials (Jeltim), 3(1), 25-38

Copyright ( 2021 by Jeltim, e-ISSN 2657-1617 
from the observation checklists, field note sheets, interview recordings, school documents, and test answers were organized by following the logic of the research questions that were presented earlier in the research design.

In the first cycle of the action steps, it was found that the classroom problems arose from both sides: tear side and learner side. In the teaching activity, the teacher just presented the prepared materials and was done not in detail and not quite obvious to the learners. The learners were not involved actively and were not really enthusiastic in the process of teaching learning in the classroom. This situation might be derived from or might have created negative attitudes towards the activities and materials of writing. What happened in the class was not in line with the steps that were written in the lesson plan, particularly when the learners tried to generate their ideas. Some of them kept asking the seatmates. The teacher seemed forced to approach every single learners around the classroom in order to explain to the learners how to generate their ideas based on the given topic. The teacher found it difficult to manage the class activities based on the time planning. She was not able to get the learners' responses of questions that were relevant to the topic and to find a conclusion concerning the topic and activities.

It is found that the majority of the learners had low ability in writing, particularly recount text. The learners' individual scores showed that 19 learners that did recount text writing still did not show good achievement on their clustering works. There were only few learners who made the clustering of ideas about the first day at MTs Darussalam well. The data indicate that the learners failed in generating and elaborating ideas. Their writing did not include the orientation properly. This might be caused by their limited knowledge about how to generate their ideas. Besides, they failed in selecting word. They were confused to change the verb into past tenses. They also made wrong choices of words to use in their ideas cluster. They had difficulties in generating ideas due to of their limited vocabularies. They also made mistakes in using verb to be in their clustering works.

In the reflection process, the teacher researcher and the collaborator identified problems that needed to be solved; to be prepared for the teaching and learning process of the following cycle. Based on the problems identification explained previously, the researcher came to the following solutions.

a) The teacher needs to explain the more details related to clustering technique. The teacher needs to simplify it.

b) The researcher needed to give more guidance in making clustering technique. 
c) The learners were still confused in using appropriate vocabularies to be applied in their list of ideas.

d) The process of clustering worked well and the learners were enthusiastic to join the activity.

e) The researcher still needed to gain learners attitude towards the recount text.

f) The process of clustering technique was still overlap especially in generating ideas and using past form. It made the learners confused because they did so many activities.

g) The procedure of clustering technique need to be improved especially the process of clustering.

In the second cycle, many learners in the class were enthusiastically following the class activities. The teacher researcher presented the materials and demonstrated clustering technique to learners. There was a remarkable progress of the quality of the classroom interaction process. Some of the learners were still silent because they did not know how to respond to the activities but many of them showed their willingness to participate by raising hand or by showing their involvement in the class activities.

The learners were enthusiastic when making their own clustering related to the topic given. While the learners made their clustering, the teacher moved around the class to help the learners generate the ideas using clustering technique. Some learners also showed their good progress in writing. They started to show their positive attitudes towards writing. Many of the learners got to understand the way to write a recount text in the right way.

The teacher found it easier to control the class in the second cycle than in the first one. The many of the learners did their best to follow up their teachers' instruction because the instruction seemed understandable. When moving around the class to offer help to the learners, the teacher found some learners asked questions. The questions raised by the learners were relevant even though the teacher needed to figure out the meaning of the questions. Before closing the meeting, the learners were asked whether they understood what they should do when writing a recount text and to summarize what they had learned. Only some of them responded and could summarize the materials. Teacher also did the group interview to support the result of research.

We found the process of the activities in the second cycle run better than it was in the first cycle. We may say, it was a progress from bad to average and was leading to good. The learners showed their improvement in this second cycle. The percentage of the learners' recount text can be seen in Chart 2. The majority of the learners' scores showed that they were in the average level. There were only few learners wrote recount text about unforgettable birthday

Journal of English Language Teaching Innovations and Materials (Jeltim), 3(1), 25-38

Copyright ( 2021 by Jeltim, e-ISSN 2657-1617 
well. The low scores indicated that the learners did not understand the way a recount text should be written. When grading, we found some learners began their writing in the right way while many of them still made mistake in making the introduction properly by following the questions related to recount text which are when, who, where and what. They still made mistakes in term of word choice and the arrangement of words into good ideas arrangement. Besides, some of them still ignored the past form of words used in the ideas.

We found the result of the 22 learners' scores of recount text writing test were good. The showed progress in their learning and in their achievement. In contrast, there was good achievement achieved by the learners on their works. As it can be seen from their own works, they showed good achievement in generating ideas.

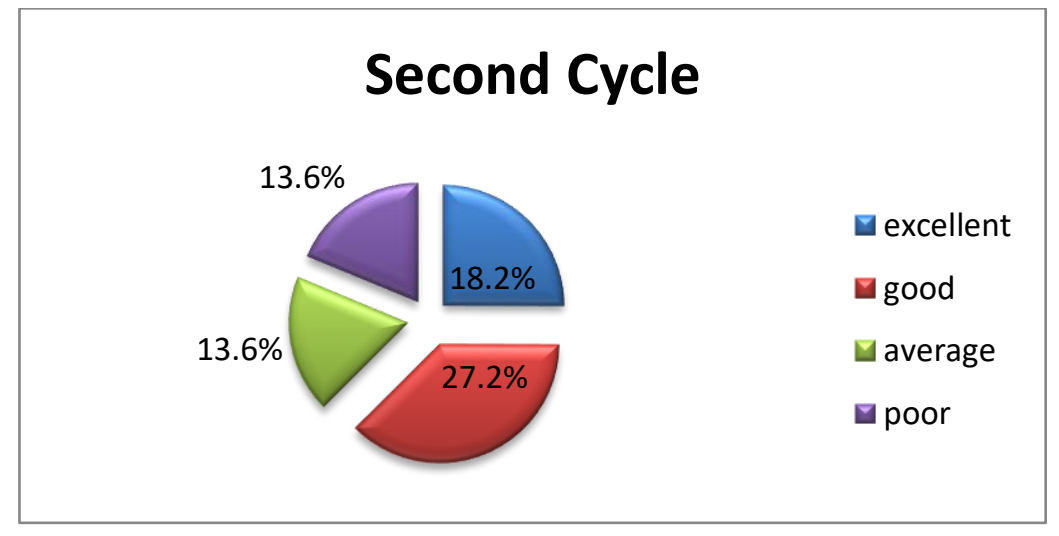

Chart 2. Learners' Second Cycle Writing Test Result

The learners' individual scores in Cycle 2 showed that many of 22 learners who were taking the test of clustering work in the second cycle, still did not show well achievement. As it elaborated that there were few learners still did not achieve the good requirements in generating ideas. However, we found improvement performed by the learners in this cycle.

Based on the result of the reflection, the teacher researcher noted some problems that need to be followed up in the following cycle, namely:

a) the researcher needs to give more guidance in making clustering technique;

b) the learners were still confused in using appropriate vocabularies especially past tense form;

c) the process of clustering worked well and the learners were enthusiastic to join the activity; and

d) the learners also still did not show a good attitude toward the implementation of clustering technique in the classroom. 
The class situation in the third cycle was vivid. The learners were enthusiastic in following and respond to the learning process. The learners showed their positive attitudes toward the learning process. The learners were brave in expressing ideas and able to mention the vocabularies related to the topic.

The teacher explained the materials well and demonstrated the clustering technique clearly. She presented the components of recount text and the steps of writing recount text. Some examples of recount text were presented and explained communicatively. The teacher also invite the learners to writing recount texts by providing some key words related to the topic in order to help the learners develop ideas and sentences in on their clustering. The procedures and the mechanics of writing recount texts were also presented to guide the learners in their writing.

The learners' enthusiasm in this cycle were much better that their enthusiasm in the previous cycles. They followed up the teacher's direction right away. It seems they understood what they should do and how they should write to produce a recount text. The interaction between the teacher and the learners were productive. The learners found it easier to write when the teacher allowed them to consult their dictionary. They also consult their writing to the teacher to make sure what they wrote were correct. The teacher they got more motivated to help the learners. She moved around the class to monitor and to offer help to the learners. What she did was also helpful to control the learners' activities; particularly to manage the class in order the learners really followed up her direction. The teacher then found the learners did their best to write recount texts properly by the use of clustering technique to help them generate ideas on their prewriting.

Most of the learners were still not achieve good achievement in generating ideas. The chat below presented the result of the 22 learners' performance in the writing test as a part of the third cycle of this study.

\section{Third Cycle}

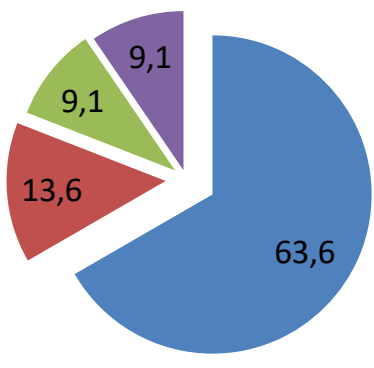

excellent

good

average

poor

Journal of English Language Teaching Innovations and Materials (Jeltim), 3(1), 25-38

Copyright ( 2021 by Jeltim, e-ISSN 2657-1617 


\section{Chart 2. Learners' Third Cycle Writing Test Result}

The researcher as the teacher and the collaborator evaluated the learners' achievement to write a recount text by using the clustering technique together. They concluded that from the works that learners shown the good achievement, so that this cycle could be stopped. The results of the learners in this cycle fulfilled the good achievement that accomplished the requirements. The learners could generate the orientation, events and re - orientation properly. Finally, they could organize their ideas into a recount text. Therefore, the researcher convinced to stop this research. In short, clustering technique helps learners to generate ideas which used to be the problems before writing

\section{DISCUSSION}

Based on the finding which had been displayed, the researcher claims that the teaching and learning process of generating ideas by using clustering technique of recount text writing was effective. Here, the learners were helped to improve their ability in generating ideas. While getting involved in the process of learning, the learners showed their feeling of excitement toward the activities in the class. At first, the learners faced difficulties in generating ideas. They were difficult to generate their ideas because they were confused how to start at first. As the applied the clustering technique, they generated their ideas quickly and they could easily generate the ideas through clustering technique. Besides, the learners filled the clustering dealing with introduction, events and conclusion easily. They looked feeling fun, interested, and motivated in the activities of generating ideas for recount text writing. Clustering technique is an effective tool for the prewriting stage of the writing process. Clustering can be useful for any kind of writing. The researcher could find that clustering technique could be simple and easy to be applied in teaching writing. Therefore, this technique can be considered helpful for the learners to stimulate and to organize their ideas before they develop them into paragraphs. Besides, this technique can motivate them to write.

Kalandadze (2007) stated that clustering an activity of making a visual map that organizes ideas, so it will be more real that only the ideas in the learners' mind. Whereas, as cited in Carol 1987, D'Aoust wrote that clustering technique of writing could be used to help writers start their writing, particularly in prewriting activity. So, it is important to note that clustering is a creative thinking process in a prewriting technique or activity. When writers are using clustering technique, they do their best to find relevant ides to be attached to writing in a certain topic. They visualize the ideas into a scratch or diagram. It is useful for writers to understand the relations between the main idea and the supporting ideas and the relation between the topic and the sub topics. So,

Journal of English Language Teaching Innovations and Materials (Jeltim), 3(1), 25-38

Copyright ( 2021 by Jeltim, e-ISSN 2657-1617 
clustering can help learners organize their ideas. It is helpful for them to jot down the ideas that they have in their minds right away.

Overall, clustering technique had improved learners' understanding in generating the ideas. By generating the ideas through the clustering technique, a creative and motivating atmosphere could be created. Teachers can take some benefits from implementing clustering technique in their classes because the technique can help learners collect and organize thoughts prior to beginning writing. Thus, this technique is really helpful for the learners to encourage and help them to generate ideas in prewriting stage. The learners showed good achievement of their generate $\mathrm{g}$ ideas as it can be seen from their clustering works. It showed that there was improvement of learners' individual cluster. It means that the clustering technique successfully helped the learners to generate the ideas.

Based on the qualitative data gained by conducting observation, it was clearly seen that the use of clustering technique made the good effect to the learners. At first, the learners did not have much enthusiasm in generating ideas. They tended to afraid in expressing their idea. They were afraid of making mistake because they did not have enough vocabularies and ideas on their mind. There were only few learners asked and answered question to the teacher. They were not active and still needed motivation from the teacher. The class situation was not controlled well, there were still some learners were busy to themselves. Furthermore, in the second cycle the learners gave their full attention to the teacher and some of them looked interested and enjoy during the implementation of clustering technique in generating ideas of recount text writing. But, there were also some learners who got confused in finding vocabulary to be applied in their ideas development.

Meanwhile, in the third cycle the teacher set new plan to make learners overcome their problem. Based on the reflection in the previous cycle the researcher decided to give more examples in implementing clustering technique and delivered question guidelines as the stimulus to build learners motivation in generating ideas as the topic given. It brought positive response to the learners. They showed their interest and enthusiastic in generating ideas by using the clustering technique. They began to familiar with the clustering technique, and they began to have their self confidence in generating ideas. The class situation were active than before. The learners dared to explore their ideas. Then, the class situation was comfortable and controlled well. It can be seen from the learners' attitude during teaching learning process. Most of them paid attention to the teacher explanation. It showed that the learners enjoy the teaching learning process.

Journal of English Language Teaching Innovations and Materials (Jeltim), 3(1), 25-38

Copyright ( 2021 by Jeltim, e-ISSN 2657-1617 
In short, the sequence process of generating ideas by using clustering technique of recount text writing provided a good progress in improving learners' ability in generating ideas. By clustering the ideas helped learners develop their critical thinking in finding as much ideas to be described in their clusters. Learners were able to concept ideas on their cluster. Clustering technique was also a motivating activity for them since it created an enjoyable and fun learning. Clustering technique was effective for learner in generating ideas. It was easy to use and relevant for learners in all age. Clustering technique helped learners to generate and organize ideas. It promoted an active learning, reduced anxiety and created a fun learning. Moreover, the learners' achievement in generating ideas by using clustering technique of recount text writing had been improved in each cycle significantly. It had been proved with the data gained by the researcher from learners' tests in each cycle.

Last but not least, the finding that clustering activities could improve the learners' motivation and enthusiasm is important. Learners will learn better if they are enthusiastic and motivated. It is in line with what has been done by Ikhsanudin (2017) in improving engagement using magic trick activities and Ikhsanudin, Sudarsono, and Salam (2019) in the implementation of magic tricks to improve learners' engagement in a listening class. Motivation and enthusiasm that exist in a classroom situation is believed to be able to improve the learners' engagement and improve the quality of the teaching and learning interaction.

\section{CONCLUSION}

Referring to the finding and discussion, clustering has improved learners' ability in generating ideas of recount text writing. The result shows that the learners are able to develop their ideas and find the easy way to organize their ideas by using clustering technique. Moreover, they are able to use and cluster their ideas as the concept of recount text writing into simple sentences. It motivates them generate their ideas in recount text writing as they thought was difficult before. Therefore, clustering technique is beneficial for learners to improve their ability in generating ideas. It is suggested English teachers introduce or implement the clustering activities in their writing class, particularly to help learners in generating ideas of writing. When implementing the activity, an English teacher should help the learners by approaching them to offer help or eliciting questions.

\section{REFERENCES}

Adams, W. R. (2010). Viewpoints: readings worth thinking and writer about. Boston: Wadsworth Cengage Learning.

Journal of English Language Teaching Innovations and Materials (Jeltim), 3(1), 25-38

Copyright ( 2021 by Jeltim, e-ISSN 2657-1617 
Adriati, M. (2013). The Use of Clustering Technique in Teaching Writing Narrative Text. Bandung: Journal of English and Education

Al-Roomy, M. (2016).Developing Learners' EFL Writing Skills by Enhancing their Oral Interactions.International Journal of Applied Linguistics $\mathcal{E}$ English Literature, 5.24-31

Al-Shourafa, A. (2012). The Effect of Motivation on Jordanian 10th Grade Learners' Writing Skill in English.European Scientific Journal , 22. 235 247

Anderson, Linda (2006). Creative Writing: A Workbook with Readings. London: Routledge

Aten, Jerry. (2007). Skill Builders Writing Grades 7 - 8. North Carolina: Rainbow Bridge Publishing

Baroudy, I. (2008). "A Procedural Approach to Process Theory of Writing: Prewriting Techniques". The International Journal of Language Society and Culture, 24

Burns, A. (2010). Doing Action Research in English Language Teaching: A Guide for Practitioners. New York: Taylor and Francis

Caswell, Roger \& Mahler, Brenda.(2004). Strategies for Teaching Writing. Virginia: Association for Supervision and Curriculum Development.

Cohen, L., Manio, L., \& Morrison, K. (2007).Research Methods in Education (6th $E d)$. New York: Routledge.

Creswell, J. W. (2012). Educational Research: Planning, Conducting, and Evaluating Quantitative, and Qualitative Research (4th Ed). Boston: Pearson Educaation, Inc.

DePorter, Bobbi \& Mike Hernacki.(1999). Quantum Learning. Bandung: Kaifa.

Dong,Yu Ren (2004). Teaching Language and Content to Linguistically and Culturally Diverse Studnets: Principles, Ideas, and Materials. United States of America: Information Age Publishing, Inc.

Elbow, P. (1981). Writing with Power: Techniques for Mastering the Writing Process $\left(2^{\text {nd }} e d\right)$. New York: Oxford University Press, Inc.

Ferrance, Eileen. (2000). Themes in Education; Action Research. USA: Northeast and Islands Regional Educational Laboratory at Brown University.

Gorski, A. Victoria. (2010). The Disadvantages of Using Concept Maps to Teach Critical Thinking.

Grenville, K. (2001). Writing from start to finish : A six-step guide.Sydney :Allen \&Unwin.

Grififth University. (2004). Written Communication Toolkit. Australia: Griffith Institute for Higher Education.

Halpern, Diane F. (2013). Critical Thinking Across the Curriculum: A Brief Edition of Thought and Knowledge. New York: Routledge

Heaton, J. B. (1975) Writing English Language Test. London: Longman Group Limited.

Journal of English Language Teaching Innovations and Materials (Jeltim), 3(1), 25-38

Copyright ( 2021 by Jeltim, e-ISSN 2657-1617 
Hyland, Ken. (2004). Genre and Second Language Writing. The United State of America: The University of Michigan Press

Ikhsanudin, I. (2017). The possibility of developing English magic tricks problem-based activities to enhance senior high school students' engagement. Proceedings International Conference on Teaching and Education (ICOTE), Vol 1(1), 28-34. Retreived from https://jurnal.untan.ac.id/index.php/icote/article/view/26196

Ikhsanudin, I., Sudarsono, S., \& Salam, U. (2019). Using magic trick problembased activities to improve engagement in a listening class. Journal of English Language Teaching Innovations and Materials (JELTIM), 1(1), 7-15. DOI: $10.26418 /$ jeltim.v1i1.31620

Kellog, Ronald. T. (1994).The psychology of Writing. New York: Oxford University Press

Koshi, V. (2009). Action Research for Improving Practice. London: Paul Chapman Publishing.

Murcia, M. C. (2001). Teaching English as a Second or Foreign Language. United States of America: Thomson Learning, Inc.

Matthews, Janice. R. \& Matthews, Robert. W. (2008).Successful Scientific Writing. New York: Cambridge University Press

Mazza, Nicholas. (2003). Poetry Theraphy. New York and Hove: Brunner Routledge

Norton, L. S. 2009. Action research in teaching and learning: A practical guide to conducting pedagogical research in university. New York: Routledge.

Oshima, A. \& Hogue, A. (1998). Introduction to Academic Writing (3 ${ }^{\text {nd }}$ Ed). New York: Addison Wesley Longman, Inc.

Palmer, Sue. (2003). How To Teach Writing Across the Curriculum: Ages 8 - 14. New York: Routledge

Patty \& Steels, Jeannie. L. (1991). The Thinking-Writing Connection: Using Clustering to Help Learners Write Persuasively. Reading Horizons, 32, 41 - 51

Puengpipattrakul, W. (2014).A Process Approach to Writing to Develop Thai EFL Learners' Socio-Cognitive Skills.Electronic Journal of Foreign Language Teaching. 2, 270-284.

Richard. M. (1990).Suggestion Ideas for Beginning and Teachers. New York: University Press of America.

Scarry, John \&Scarry, Sandra. (2018). The Writer's Workplace: Building College Writing Skills. Boston: Cengage Learning.

Seliger,W. \&Shohamy, E. (1989). Second Language Research Methods. Hong Kong: Oxford University

Soifer, Rena. (1990). The Complete Theory to Practice Handbook of Adult Literacy. New York: Teacher College PressSteels,

Sorenson, S. (2010).Webster's New World.Learner Writing Handbook (5th Ed). Canada: Wiley Pubishing. Inc. 
Steels, Patty \& Steels, Jeannie. L. (1991). The Thinking-Writing Connection: Using Clustering to Help Learners Write Persuasively. Reading Horizons, $32,41-51$

Stockton, Helen. (2014). Teaching Creative Writing. UK: How to BooksTrimble, Trimble,Richard.M. (1990).Suggestion Ideas for Beginning and Teachers. New York: University Press of America.

Warner, Margaret. (2009). Easy Text Types.Greenwood: Ready Ed - Publication. Zemach, D. E. \&Rumisek, L. A. (2005). Academic Writing from Paragraph to Essay. Macmillan: Cambridge University

\section{Authors' Brief CV}

Hilda Mutia Sari graduated from Master Study Program of English Language Education, Teacher Training and Education Faculty, Universitas Tanjungpura, Pontianak, Indonesia. During studying in the university she was actively attending and presenting at international conferences. She is now an independent educator in Kuching, Sarawak, Malaysia.

Yohanes Gatot Sutapa Yuliana is a lecturer of Undergraduate and Master Study Program of English Language Education of Tanjungpura University. He wrote his doctoral dissertation on English teaching material development for vocational schools. He also attended sandwich-like for visiting scholar program in University of Illinois at Urbana USA 2010, and Community Development Program in Kansas State Univeristy 2019. On his professional duties, he teaches Research Approaches, TEFL Assessment, TEFL Methodologies, Academic Writing and Presentation, and Research Paper.

Clarry Sada obtained his Master's Degree in English Language Teaching from the Institut Keguruan dan Ilmu Pendidikan Negeri Malang and Doctor of Education from Universitas Pendidikan Indonesia. He is now a lecturer of Undergraduate and Master Study Program of English Language Education of Universitas Tanjungpura, Pontianak - Indonesia. 